\title{
Family correlates of fruit and vegetable consumption in children and adolescents: a systematic review
}

\author{
Natalie Pearson*, Stuart JH Biddle and Trish Gorely \\ School of Sport and Exercise Sciences, Loughborough University, Loughborough, Leicestershire LE 11 3TU, UK
}

Submitted 22 August 2007: Accepted 16 April 2008: First published online 18 June 2008

\begin{abstract}
Objectives: To review associations between the family environment and young people's fruit and vegetable consumption.

Design: A systematic review. Published English-language ( $n$ 60) papers were identified using electronic databases and manual searches of personal files and reference lists. Observational research reporting a measure of fruit/vegetable intake for children (aged 6-11 years) and/or adolescents (aged 12-18 years) and at least one potential family correlate of dietary intake was included.

Results: Parental modelling and parental intake were consistently and positively associated with children's fruit and fruit, juice and vegetable (FJV) consumption. There were also positive associations between home availability, family rules and parental encouragement and children's fruit and vegetable consumption. Parental intake was positively associated with adolescents' fruit and vegetable consumption. There were also positive associations between parental occupational status and adolescent fruit consumption and between parental education and adolescents' FJV consumption.

Conclusions: Our findings highlight the importance of targeting the family environment for the promotion of healthy eating behaviours among children and adolescents. Future interventions should encourage parents to be positive role models by targeting parental intake and to create a supportive home environment through increased encouragement and availability of fruits and vegetables and employing rules to govern eating behaviours. For adolescents, indicators of family circumstances (e.g. parental education) should be used to identify target groups for interventions aimed at promoting healthy eating.
\end{abstract}

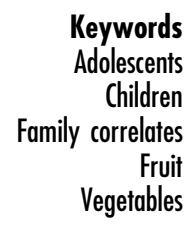

There is compelling evidence that diets rich in fruits and vegetables have health-protective effects ${ }^{(1)}$. While most of the research on associations between fruit and vegetable consumption and health outcomes has focused on adults, there is growing evidence that fruit and vegetable consumption in children may protect against a range of childhood illnesses ${ }^{(2)}$. Targeting young people to improve health behaviours, such as consuming the recommended amount of fruit and vegetables, is important because evidence suggests that dietary behaviours track from childhood to adolescence ${ }^{(3,4)}$ and food behaviour and food choices established in childhood or adolescence may significantly track into adulthood ${ }^{(5)}$. Moreover, child fruit consumption may be protective against cancer in adulthood ${ }^{(6)}$.

Recommendations vary by country but public health agendas across the globe share the common goals of increasing the consumption levels of fruit and vegetables and encouraging people to eat a variety of fruit and vegetables. Despite the health benefits of diets rich in fruits and vegetables, national health surveys indicate that children and adolescents are eating fewer fruits and vegetables than is recommended for health ${ }^{(7-9)}$. Data from the Health Behaviour in School-aged Children study (HBSC) shows that less than two-fifths of young people eat fruit daily, and only about a third eat vegetables each day $^{(10)}$. Identifying correlates of fruit and vegetable consumption may be of importance in pursuit of increasing overall consumption.

According to social ecological theory, the environment plays an important role in shaping behaviours by supporting or hindering behaviours that occur within it $^{(11)}$. These environments include settings such as the family, school, community or legislative/policy environment. The family is critical in the general socialisation of children ${ }^{(12)}$ and is a prominent element of the social environment where dietary behaviours are enacted and learned ${ }^{(13)}$. Moreover, there is convincing evidence that the family environment is important in influencing the dietary behaviours of young people $\mathrm{e}^{(14-17)}$. A recent systematic review of environmental correlates of obesity-related dietary behaviours in youth found that environmental factors were most consistently studied at the household 
level, and that parental intake was consistently associated with youth's dietary intake ${ }^{(18)}$. Similarly, Rasmussen et al. ${ }^{(19)}$ found that parental intake and home availability/accessibility were some of the most consistently supported determinants of fruit and vegetable consumption in young people.

The current review aims to develop and add to the findings of Rasmussen et al. ${ }^{(19)}$ and van der Horst et al. ${ }^{(18)}$ by updating the evidence for fruit and vegetable consumption, focusing specifically on family correlates and by reporting the results and findings for fruit and vegetables separately. This review focuses on school-aged children (6-18 years) because this covers the complex and dynamic time periods where behaviours may begin to be influenced by other social and environmental factors. This is a time frame also where young people are, in the majority, still living at home and potentially eating up to three meals a day in the home/family environment. van der Horst et $a l .{ }^{(18)}$ included pre-school children but made no distinction in the results or discussion between preschool and school-aged children. The differences are likely to be quite marked due to pre-school children being totally dependent on the family. Rasmussen et al. ${ }^{(19)}$ also looked at school-aged children (aged 6-18) but made no distinction in the results between the different family factors associated with children and with adolescents. Children and adolescents need to be understood separately because they are psychologically and psychosocially at different stages of maturation and diverse social influences will be acting upon them. Thus we decided to focus specifically on the family environment to investigate the correlates associated with fruit and vegetable consumption of children and adolescents of school age.

\section{Methods}

This study followed the procedures for a systematic review produced by the NHS Centre for Reviews and Dissemination $^{(20)}$.

\section{Search strategy}

Key terms for young people's dietary intake were used in combination with key terms for family factors to locate potentially relevant studies. Key terms for young people's dietary behaviours included healthy eating, eating behaviours, diet, nutrition, feeding behaviours, fruit, fruit intake, vegetables, vegetable intake, young people, adolescent and child. Key terms for family factors included family influence, parental influence, family-child, family determinants, family and sibling. The following electronic databases were searched using the key terms: Science Direct, PubMed, PsychINFO, Medline and Web of Science. In addition to electronic searches, manual searches of personal files were conducted along with screening reference lists of review studies and identified articles for titles that included the key terms.

\section{Inclusion and exclusion criteria}

For inclusion, studies were required to (i) include children aged 6-11 years and/or adolescents aged 12-18 years (or a mean within these ranges) as subjects of study; (ii) have a measure of the child's or adolescent's fruit and/or fruit juice and/or vegetables and/or a composite measure of fruit, fruit juice and vegetables (FJV) as the dependent variable; (iii) have an outcome measure that was assessed for at least one complete day; (iv) measure at least one potential family correlate of child/adolescent dietary intake; (v) articles published in peer-reviewed journals in the English language; and (vii) articles published up to February 2007. Intervention studies, studies where pre-school children, overweight/obese children or adults were the only participants and studies focusing on eating disorders were excluded.

\section{Identification of relevant studies}

Potentially relevant papers were selected by (i) screening the titles; (ii) screening the abstracts; and (iii) if abstracts were not available or did not provide sufficient data, the entire article was retrieved and screened to determine whether it met the inclusion criteria.

\section{Data extraction}

Data from the included studies were extracted by the first author on standardised forms developed for this review. The following data were extracted: author, date and country of study, study design, characteristics of the participants (sample size, age, gender), measures of dietary variables, dietary outcome, assessment methodology and reliability and validity of dietary measures. This information is summarised in Table 1 . In addition, the reliability and validity of measures of physical and sociocultural family correlates and the response rates for each study were extracted (data not shown in tables).

Identified family correlates and study findings were extracted and data were tabulated to highlight the state of the literature for each dietary outcome and identified family correlates for children (see Tables 2 and 3) and adolescents (see Tables 4-7). Discrepancies ( $n$ 7) over the extracted data were solved through discussion by the first and second authors. Potential family correlates were classified into three categories: physical family factors (e.g. availability of foods), sociocultural factors (e.g. parental intake) and demographic factors (e.g. parental education).

\section{Coding associations with dietary outcomes}

Studies that found significant associations between family correlates and dietary outcomes were entered into the 'related to dietary behaviours' column and the directions of the associations were coded as ' + ' for positive associations or '- ' for inverse associations. Studies finding no significant associations were entered into the 'unrelated to dietary behaviours' column. All identified family correlates are displayed in the summary tables, but only those 
reported in three or more samples (defined as having three or more samples in the 'No. of samples' column in Tables 2-7) are presented in the results. These coding rules are based on Sallis et $a l^{(21)}$. For the most part, articles reported univariate tests assessing the significance of associations. Thus, even if multivariate tests were conducted, univariate tests were reported for consistency across studies.

\section{Summary codes}

An independent sample was used as the unit of analysis and was defined as the smallest independent sub-sample for which relevant data were reported (e.g. boys/girls) ${ }^{(22)}$. The column 'number of samples' displays the number of samples that have been studied for each identified correlate. The 'summary' column contains the number of samples finding positive (+), inverse (-) and no (0) associations for each family correlate. Based on the per cent of findings supporting the association (number of associations supporting the expected association divided by the total number of associations for that variable), the variable was classified as no association (0-33\%), indeterminate/inconsistent (34-59\%) and positive or negative association (60-100\%). Such rules for classifying variables regarding strength of evidence of association have been used previously ${ }^{(21)}$. Classifications of variables will not be displayed in tables but will be used to distinguish important variables for discussion.

The quality of the studies included in the review was assessed. Studies were given scores based on their level of reporting the reliability and validity of measures used to assess physical and sociocultural family correlates. Scores were 0 for no report, 1 for reporting reliability and/or validity of some of the measures used and 2 for reporting reliability and/or validity of all measures, resulting in a highest possible score of 4 (e.g. 2 points for reporting validity and 2 points for reporting reliability). We examined the response rates of those studies scoring 3 or 4 points, and studies with response rates of over $60 \%$ were classified as high quality.

\section{Results}

The literature searches yielded 11987 titles of potentially relevant articles (see Fig. 1) and sixty papers (eighty-eight samples) were eligible for this review. Results are reported separately for children and adolescents.

\section{Family correlates of children's dietary intake}

Twenty-five studies (thirty-three samples) of children were reviewed (see Table 1). The majority of studies were

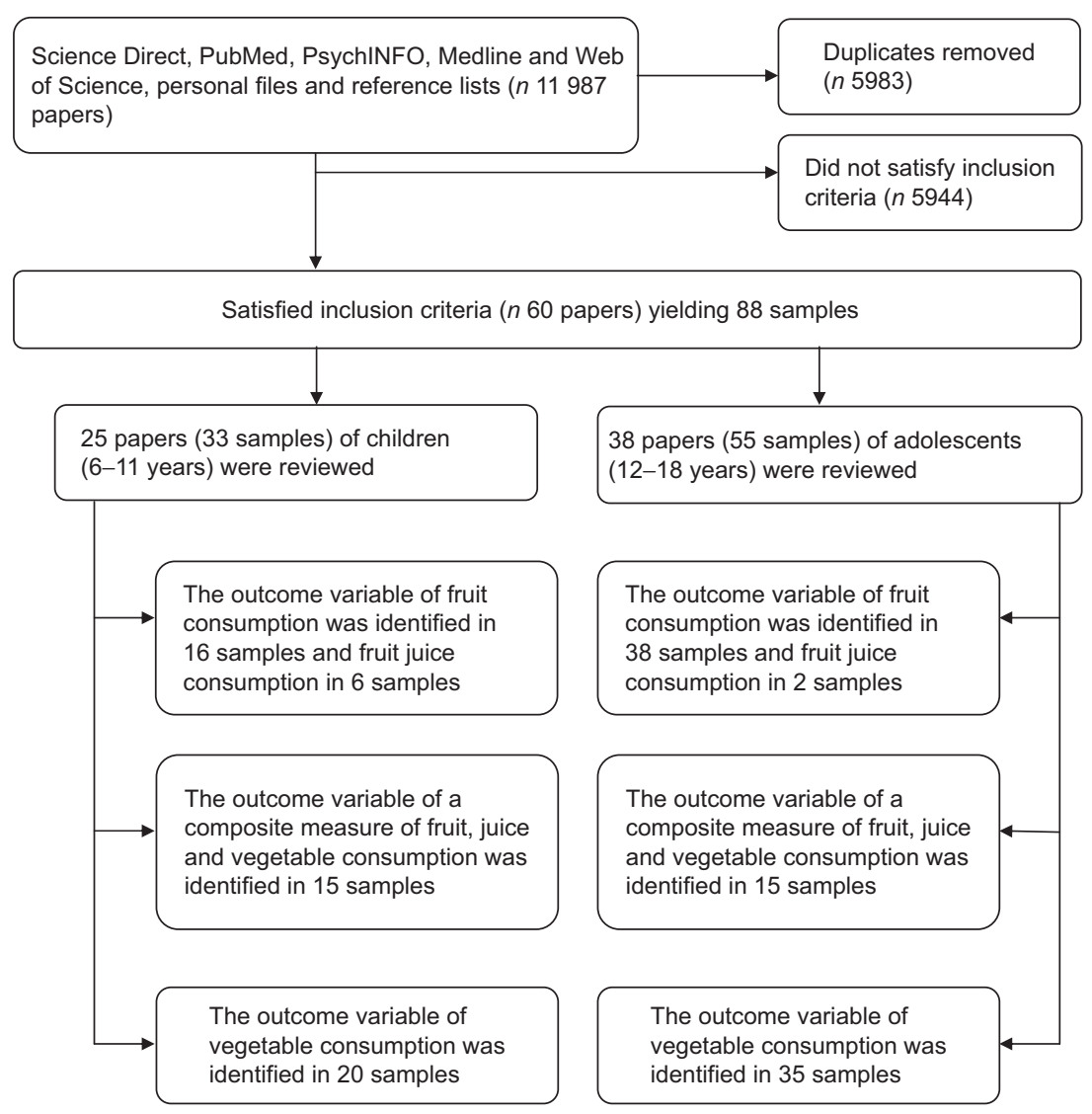

Fig. 1 Flow chart of literature search and sample identification 


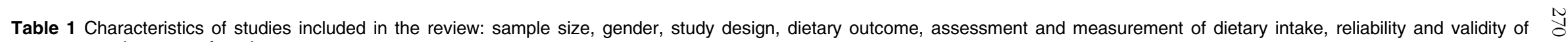
measures and country of study

\begin{tabular}{|c|c|c|c|c|c|c|}
\hline & \multicolumn{3}{|l|}{ Children (6-11 years) } & \multicolumn{3}{|l|}{ Adolescents (12-18 years) } \\
\hline & References & $\begin{array}{l}\text { No. of } \\
\text { samples }\end{array}$ & $\%$ & References & $\begin{array}{l}\text { No. of } \\
\text { samples }\end{array}$ & $\%$ \\
\hline Sample size & & 33 & 100 & & 55 & 100 \\
\hline$<100$ & {$[34,36 \mathrm{~B}, 36 \mathrm{G}, 42 \mathrm{G}, 44,56,61$ I II] } & 8 & 24 & {$[26,43 \mathrm{~B}]$} & 2 & 4 \\
\hline $100-199$ & [35 G, 38] & 2 & 6 & {$[40,59 \mathrm{~B}, 59 \mathrm{G}, 85 \mathrm{~B}]$} & 3 & 7 \\
\hline 200-299 & [37] & 1 & 3 & {$[29,39 \mathrm{~B}, 39 \mathrm{G}, 55 \mathrm{G}]$} & 3 & 7 \\
\hline $300-499$ & {$[46]$} & 1 & 3 & {$[45 \mathrm{~B}, 45 \mathrm{G}, 47 \mathrm{~B}, 47 \mathrm{G}, 55 \mathrm{~B}, 69 \mathrm{~B}, 69 \mathrm{G}, 83,84 \mathrm{~B}, 84 \mathrm{G}, 85 \mathrm{G}]$} & 11 & 20 \\
\hline 500-999 & [30 । II, 33, 41 B II, 62 I II] & 6 & 19 & {$[32,52,60,66]$} & 4 & 7 \\
\hline $1000-2999$ & {$[28,31,51,53,67,75 \mathrm{~B}, 75 \mathrm{G}, 76 \mathrm{~B}, 76 \mathrm{G}, 77]$} & 10 & 30 & {$[27 \mathrm{~B}, 27 \mathrm{G}, 28 \mathrm{~B}, 28 \mathrm{G}, 54 \mathrm{~B}, 54 \mathrm{G}, 71,78 \mathrm{~B} / \mathrm{G}, 79 \mathrm{~B} / \mathrm{G}, 80]$} & 12 & 22 \\
\hline $3000-4999$ & {$[27 \mathrm{~B}, 27 \mathrm{G}, 41 \mathrm{~B} \mathrm{I}]$} & 3 & 9 & {$[50,57 \mathrm{~B}, 57 \mathrm{G}, 58,63,65,81,82]$} & 8 & 14 \\
\hline$>5000$ & & 0 & 0 & {$[49 \mathrm{~B} / \mathrm{G}, 64,68 \mathrm{~B}, 68 \mathrm{G}, 70,72,73 \mathrm{~B} / \mathrm{G}, 74]$} & 10 & 19 \\
\hline Unknown & {$[26,48]$} & 2 & 6 & & 0 & 0 \\
\hline \multicolumn{7}{|l|}{ Gender } \\
\hline Girls only & {$[35,42]$} & 2 & 6 & & 0 & 0 \\
\hline Boys only & {$[41 \mid I I]$} & 2 & 6 & {$[43 \mathrm{~B}]$} & 1 & 2 \\
\hline Boys and girls combined & $\begin{array}{l}{[26,28,30 \text { I II, 31, 33, 34, 37, 38, 44, 46, 48, 51, 53, }} \\
\quad 56,61 \text { III, } 62 \text { I II, 67, 77] }\end{array}$ & 21 & 64 & $\begin{array}{l}{[26,29,32,40,50,52,58,60,63,64,65,66,70,71,72,74,80,} \\
\quad 81,82,83]\end{array}$ & 20 & 36 \\
\hline Boys and girls separately & {$[27,36,75,76]$} & 8 & 24 & {$[27,28,39,45,47,49,54,55,57,59,68,69,73,78,79,84,85]$} & 34 & 62 \\
\hline \multicolumn{7}{|c|}{ 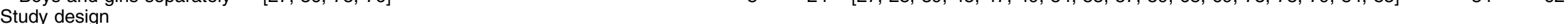 } \\
\hline Cross-sectional & $\begin{array}{l}{[26,27 \mathrm{~B} / \mathrm{G}, 28,31,33,34,35 \mathrm{G}, 36 \mathrm{~B} / \mathrm{G}, 37,38,41} \\
\text { B I II, 42 G, 44, 46, 48,51, 53, 56, 61 III, 62 I II, } 67 \\
75 \mathrm{~B} / \mathrm{G}, 76 \mathrm{~B} / \mathrm{G}, 77]\end{array}$ & 31 & 94 & $\begin{array}{l}{[26,27 \mathrm{~B} / \mathrm{G}, 28 \mathrm{~B} / \mathrm{G}, 29,32,39 \mathrm{~B} / \mathrm{G}, 40,43 \mathrm{~B}, 45 \mathrm{~B} / \mathrm{G}, 47 \mathrm{~B} / \mathrm{G}} \\
49 \mathrm{~B} / \mathrm{G}, 50,52,54 \mathrm{~B} / \mathrm{G}, 55^{1} \mathrm{~B} / \mathrm{G}, 58,57 \mathrm{~B} / \mathrm{G}, 59^{1} \mathrm{~B} / \mathrm{G}, 60,63,64 \\
65,66,68 \mathrm{~B} / \mathrm{G}, 69 \mathrm{~B} / \mathrm{G}, 70,71^{1}, 72,73 \mathrm{~B} / \mathrm{G}, 74,78 \mathrm{~B} / \mathrm{G}, 79 \mathrm{~B} / \mathrm{G} \\
80,81,82,83,84 \mathrm{~B} / \mathrm{G}, 85 \mathrm{~B} / \mathrm{G}]\end{array}$ & 55 & 100 \\
\hline Longitudinal (prospective) & [30 I II 9 months] & 2 & 6 & & 0 & 0 \\
\hline \multicolumn{7}{|l|}{ Dietary outcome } \\
\hline Fruit & $\begin{array}{l}{[27 \mathrm{~B} / \mathrm{G}, 28,34,35 \mathrm{G}, 37,44,46,48,53,56,61 \mathrm{I} I \mathrm{I}} \\
67,76 \mathrm{~B} / \mathrm{G}]\end{array}$ & 16 & 48 & $\begin{array}{r}{[27 \mathrm{~B} / \mathrm{G}, 28 \mathrm{~B} / \mathrm{G}, 29,32,39 \mathrm{~B} / \mathrm{G}, 40,43 \mathrm{~B}, 45 \mathrm{~B} / \mathrm{G}, 47 \mathrm{~B} / \mathrm{G}, 49 \mathrm{~B} / \mathrm{G}, 52,54 \mathrm{~B} /} \\
\mathrm{G}, 59 \mathrm{~B} / \mathrm{G}, 60,63,64,66,69 \mathrm{~B} / \mathrm{G}, 70,71,72,73 \mathrm{~B} / \mathrm{G}, 74,79 \mathrm{~B} / \mathrm{G}, 81,85 \mathrm{~B} / \mathrm{G}]\end{array}$ & 38 & 69 \\
\hline Vegetables & $\begin{array}{l}{[27 \mathrm{~B} / \mathrm{G}, 28,33,34,35 \mathrm{G}, 37,41 \mathrm{~B} \text { I II, 44, 46, 48, }} \\
53,56,61 \mathrm{II}, 67,76 \mathrm{~B} / \mathrm{G}, 77]\end{array}$ & 20 & 61 & $\begin{array}{c}{[27 \mathrm{~B} / \mathrm{G}, 28 \mathrm{~B} / \mathrm{G}, 29,32,39 \mathrm{~B} / \mathrm{G}, 40,43 \mathrm{~B}, 45 \mathrm{~B} / \mathrm{G}, 47 \mathrm{~B} / \mathrm{G}, 49 \mathrm{~B} / \mathrm{G}, 54 \mathrm{~B} / \mathrm{G}, 59} \\
\mathrm{B} / \mathrm{G}, 63,64,66,68 \mathrm{~B} / \mathrm{G}, 69 \mathrm{~B} / \mathrm{G}, 70,71,73 \mathrm{~B} / \mathrm{G}, 74,79 \mathrm{~B} / \mathrm{G}, 81]\end{array}$ & 35 & 64 \\
\hline Fruit juice & {$[34,35 \mathrm{G}, 37,44,46,56]$} & 6 & 18 & {$[43 \mathrm{~B}, 71]$} & 2 & 4 \\
\hline $\begin{array}{l}\text { Composite measure of fruit } \\
\text { and/or vegetables and/or } \\
\text { fruit juice }\end{array}$ & $\begin{array}{l}{[26,30 \text { I II, 31, 36 B/G, 37, 38, } 42 \mathrm{G}, 48,51,62 \mathrm{I} I \mathrm{I}} \\
75 \mathrm{~B} / \mathrm{G}]\end{array}$ & 15 & 45 & {$[26,50,55 \mathrm{~B} / \mathrm{G}, 57 \mathrm{~B} / \mathrm{G}, 58,65,78 \mathrm{~B} / \mathrm{G}, 80,82,83,84 \mathrm{~B} / \mathrm{G}]$} & 15 & 27 \\
\hline \multicolumn{7}{|c|}{ Assessment of dietary outcome } \\
\hline Self-report & $\begin{array}{l}{[30 \text { I II, 34, 35 G, 37, 38, } 41 \text { B I II, 51, 53, } 27 \text { B/G, } 62 \text { I }} \\
\text { II, 75 B/G, 76 B/G, 77] }\end{array}$ & 19 & 58 & $\begin{array}{c}{[27 \mathrm{~B} / \mathrm{G}, 29,40,43 \mathrm{~B}, 45 \mathrm{~B} / \mathrm{G}, 49 \mathrm{~B} / \mathrm{G}, 50,52,54 \mathrm{~B} / \mathrm{G}, 55 \mathrm{~B} / \mathrm{G},} \\
57 \mathrm{~B} / \mathrm{G}, 58,59 \mathrm{~B} / \mathrm{G}, 60,63,64,65,66,68 \mathrm{~B} / \mathrm{G}, 69 \mathrm{~B} / \mathrm{G}, 70,71 \\
72.73 \mathrm{~B} / \mathrm{G}, 74.78 \mathrm{~B} / \mathrm{G}, 79 \mathrm{~B} / \mathrm{G}, 80,81,82,83,84 \mathrm{~B} / \mathrm{G}, 85 \mathrm{~B} / \mathrm{G}]\end{array}$ & 47 & 85 \\
\hline Parent report & {$[26,28,33,67]$} & 4 & 12 & {$[26,28 \mathrm{~B} / \mathrm{G}]$} & 3 & 6 \\
\hline Self- and parent report & {$[31,36,42 \mathrm{G}, 44,46,48,56,61 \mathrm{III}]$} & 10 & 30 & {$[32,39 \mathrm{~B} / \mathrm{G}, 47 \mathrm{~B} / \mathrm{G}]$} & 5 & 9 \\
\hline \multicolumn{7}{|l|}{ Measure of dietary outcome } \\
\hline FFQ & $\begin{array}{l}{[26,30 \text { I II, 31, 33, } 41 \mathrm{~B} \text { I II, 46, 53, 67, } 75 \text { B/G, }} \\
\quad 76 \mathrm{~B} / \mathrm{G}]\end{array}$ & 14 & 43 & $\begin{array}{l}{[26,29,32,39 \mathrm{~B} / \mathrm{G}, 40,47 \mathrm{~B} / \mathrm{G}, 49 \mathrm{~B} / \mathrm{G}, 50,52,54 \mathrm{~B} / \mathrm{G}, 58,60,63,} \\
\quad 64,65,66,68 \mathrm{~B} / \mathrm{G}, 69 \mathrm{~B} / \mathrm{G}, 70,71,72,73 \mathrm{~B} / \mathrm{G}, 79 \mathrm{~B} / \mathrm{G}, 80,85 \mathrm{~B} / \mathrm{G}]\end{array}$ & 34 & 62 \\
\hline Other questionnaire & {$[27 \mathrm{~B} / \mathrm{G}, 28]$} & 3 & 9 & {$[27 \mathrm{~B} / \mathrm{G}, 28 \mathrm{~B} / \mathrm{G}, 55 \mathrm{~B} / \mathrm{G}, 57 \mathrm{~B} / \mathrm{G}, 74,80,82,83]$} & 12 & 22 \\
\hline $24 \mathrm{~h}$ recall & {$[34,35 \mathrm{G}, 51,61 \mid \mathrm{II}, 62$ । II, 77] } & 8 & 24 & {$[43 \mathrm{~B}, 45 \mathrm{~B} / \mathrm{G}, 78 \mathrm{~B} / \mathrm{G}, 84 \mathrm{~B} / \mathrm{G}]$} & 7 & 13 \\
\hline $2 d$ food diary & {$[37,38]$} & 2 & 6 & & 0 & 0 \\
\hline $3 \mathrm{~d}$ food diary & [42 G, 44] & 2 & 6 & & 0 & 0 \\
\hline $4 \mathrm{~d}$ food diary & [56] & 1 & 3 & [59 B/G] & 2 & 3 \\
\hline $7 \mathrm{~d}$ food diary & {$[36 \mathrm{~B} / \mathrm{G}, 48]$} & 3 & 9 & & 0 & 0 \\
\hline
\end{tabular}




\begin{tabular}{|c|c|c|c|c|c|c|}
\hline & \multicolumn{3}{|l|}{ Children (6-11 years) } & \multicolumn{3}{|l|}{ Adolescents (12-18 years) } \\
\hline & References & $\begin{array}{c}\text { No. of } \\
\text { samples }\end{array}$ & $\%$ & References & $\begin{array}{c}\text { No. of } \\
\text { samples }\end{array}$ & $\%$ \\
\hline \multicolumn{7}{|l|}{ Reliability of dietary measure } \\
\hline Unknown/not reported & $\begin{array}{l}{[26,27 \mathrm{~B} / \mathrm{G}, 28,36 \mathrm{~B} / \mathrm{G}, 42 \mathrm{G}, 44,46,51,56,62 \mathrm{I} \mathrm{II}} \\
\quad 67,75 \mathrm{~B} / \mathrm{G}, 77]\end{array}$ & 17 & 52 & $\begin{array}{l}{[26,27 \mathrm{~B} / \mathrm{G}, 28 \mathrm{~B} / \mathrm{G}, 29,40,45 \mathrm{~B} / \mathrm{G}, 49 \mathrm{~B} / \mathrm{G}, 50,52,57 \mathrm{~B} / \mathrm{G}, 58,60,64,} \\
\quad 66,68 \mathrm{~B} / \mathrm{G}, 69 \mathrm{~B} / \mathrm{G}, 70,71,72,74,78 \mathrm{~B} / \mathrm{G}, 82,84 \mathrm{~B} / \mathrm{G}]\end{array}$ & 32 & 58 \\
\hline Reported elsewhere & {$[30 \mathrm{III}, 34,37,38,48,53,61 \mid \mathrm{II}, 76 \mathrm{~B} / \mathrm{G}]$} & 11 & 33 & {$[32,39 \mathrm{~B} / \mathrm{G}, 47 \mathrm{~B} / \mathrm{G}, 54 \mathrm{~B} / \mathrm{G}, 59 \mathrm{~B} / \mathrm{G}, 63,73 \mathrm{~B} / \mathrm{G}, 79 \mathrm{~B} / \mathrm{G}, 81]$} & 15 & 27 \\
\hline$<0.7$ & [41 B I III] & 2 & 6 & {$[43 \mathrm{~B}, 65,83]$} & 3 & 6 \\
\hline$>0.7$ & {$[31,33,35 \mathrm{G}]$} & 3 & 9 & {$[55 \mathrm{~B} / \mathrm{G}, 80,85 \mathrm{~B} / \mathrm{G}]$} & 5 & 9 \\
\hline \multicolumn{7}{|l|}{ Validity of dietary measure } \\
\hline Unknown/not reported & {$[26,27 \mathrm{~B} / \mathrm{G}, 28,33,42 \mathrm{G}, 44,46,51,56,62 \mathrm{III}, 77]$} & 13 & 39 & $\begin{array}{r}{[26,27 \mathrm{~B} / \mathrm{G}, 28 \mathrm{~B} / \mathrm{G}, 29,43 \mathrm{~B}, 45 \mathrm{~B} / \mathrm{G}, 49 \mathrm{~B} / \mathrm{G}, 50,55 \mathrm{~B} / \mathrm{G}, 57 \mathrm{~B} / \mathrm{G}, 58,} \\
64,66,68 \mathrm{~B} / \mathrm{G}, 69 \mathrm{~B} / \mathrm{G}, 70,71,72,74,78 \mathrm{~B} / \mathrm{G}, 80,82,83,84 \mathrm{~B} / \mathrm{G}]\end{array}$ & 34 & 62 \\
\hline Reported elsewhere & $\begin{array}{l}{[30 \text { I II, 34, } 36 \mathrm{~B} / \mathrm{G}, 37,38,48,53,61 \text { I II, 67, } 75 \mathrm{~B} / \mathrm{G},} \\
\quad 76 \mathrm{~B} / \mathrm{G}]\end{array}$ & 16 & 49 & {$[32,39 \mathrm{~B} / \mathrm{G}, 40,47 \mathrm{~B} / \mathrm{G}, 52,54 \mathrm{~B} / \mathrm{G}, 59 \mathrm{~B} / \mathrm{G}, 60,63,73 \mathrm{~B} / \mathrm{G}, 79 \mathrm{~B} / \mathrm{G}, 81]$} & 18 & 33 \\
\hline$<0.7$ & {$[31,35 \mathrm{G}, 41 \mathrm{~B}$ I II] } & 4 & 12 & {$[65,85 \mathrm{~B} / \mathrm{G}]$} & 3 & 5 \\
\hline$>0 \cdot 7$ & & 0 & 0 & & 0 & 0 \\
\hline \multicolumn{7}{|l|}{ Country } \\
\hline USA & $\begin{array}{l}{[26,35 \mathrm{G}, 36 \mathrm{~B} / \mathrm{G}, 37,38,42 \mathrm{G}, 48,51,61 \mathrm{III}, 62 \mathrm{I} \mathrm{II},} \\
77]\end{array}$ & 14 & 42 & $\begin{array}{l}{[26,29,32,43 \mathrm{~B}, 47 \mathrm{~B} / \mathrm{G}, 54 \mathrm{~B} / \mathrm{G}, 57 \mathrm{~B} / \mathrm{G}, 58,63,64,65,70,74,81,82,} \\
83,84 \mathrm{~B} / \mathrm{G}]\end{array}$ & 21 & 39 \\
\hline UK & {$[34,44,56,75 \mathrm{~B} / \mathrm{G}]$} & 5 & 16 & [71] & 1 & 2 \\
\hline Australia & [33] & 1 & 3 & {$[45 \mathrm{~B} / \mathrm{G}, 59 \mathrm{~B} / \mathrm{G}, 78 \mathrm{~B} / \mathrm{G}, 79 \mathrm{~B} / \mathrm{G}, 80]$} & 9 & 17 \\
\hline Canada & [28] & 1 & 3 & {$[28 \mathrm{~B} / \mathrm{G}]$} & 2 & 3 \\
\hline The Netherlands & {$[67,76 \mathrm{~B} / \mathrm{G}]$} & 3 & 9 & {$[52,60]$} & 2 & 3 \\
\hline Belgium & & 0 & 0 & {$[40,73 \mathrm{~B} / \mathrm{G}, 85 \mathrm{~B} / \mathrm{G}]$} & 5 & 9 \\
\hline Norway & [30 I II, 31] & 3 & 9 & {$[55 \mathrm{~B} / \mathrm{G}]$} & 2 & 3 \\
\hline Finland & [46] & 1 & 3 & {$[68 \mathrm{~B} / \mathrm{G}]$} & 2 & 3 \\
\hline Brazil & & 0 & 0 & [39 B/G] & 2 & 3 \\
\hline Sweden & & 0 & 0 & [49 B/G] & 2 & 3 \\
\hline Japan & [27 B/G] & 2 & 6 & {$[27 \mathrm{~B} / \mathrm{G}]$} & 2 & 3 \\
\hline Denmark & & 0 & 0 & [50] & 1 & 2 \\
\hline Europe & [41 B I II] & 2 & 6 & [72] & 1 & 2 \\
\hline Iceland & [53] & 1 & 3 & & 0 & 0 \\
\hline Iran & & 0 & 0 & {$[66]$} & 1 & 2 \\
\hline China & & 0 & 0 & {$[69 \mathrm{~B} / \mathrm{G}]$} & 2 & 3 \\
\hline
\end{tabular}

G, girls only; B, boys only; B/G, boys and girls analysed separately. I/II, two independent samples.

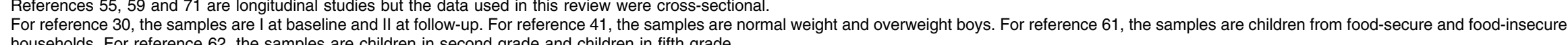

households. For reference 62, the samples are children in second grade and children in fifth grade.
References: Hannon et al. (2003) ${ }^{(26)}$; Kusano-Tsunoh et al. (2001) ${ }^{(27)}$; Myres and Kroetsch (1978) ${ }^{(28)}$; Befort et al. (2006) ${ }^{(29)}$; Bere and Klepp (2005) ${ }^{(30)}$; Bere and Klepp (2004) ${ }^{(31)}$; Boutelle et al. (2007) ${ }^{(32)}$; Campbell

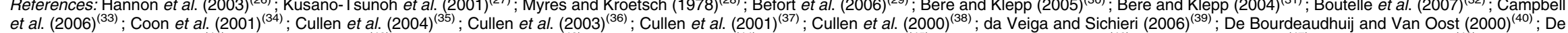
Bourdeaudhuij et al. (2006) ${ }^{(41)}$; Djuric et al. (2006) $)^{(42)}$; Edmonds et al. (2001) ${ }^{(43)}$; Gibson et al. (1998) ${ }^{(44)}$; Giskes et al. (2002) ${ }^{(45)}$; Haapalahti et al. (2003) ${ }^{(46)}$; Hanson et al. (2005) ${ }^{(47)}$; Hearn et al. (1998) ${ }^{(48)}$; Hoglund et

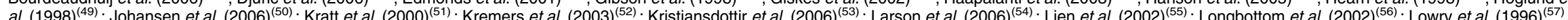
al. (1)

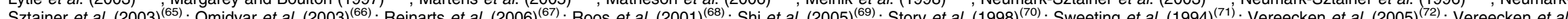
(2004) (73). Vid. Young and Fors (2001)(82); Young et al. (2004) ${ }^{(83)} ;$ Zabinski 
conducted in the USA ( $n$ 11) and in European countries ( $n$ 11). Twenty-one studies examined associations between family correlates and dietary outcomes for boys and girls combined, four examined associations separately for boys and girls, two studies examined associations for girls only and one examined associations for boys only. The majority used a cross-sectional design ( $n$ 24), over half of the studies assessed dietary outcomes through self-report ( $n$ 13), with FFQ ( $n$ 10) being the most frequently used measure. The average sample size was 1131 (range $=36-8263$ ). Only three studies reported the validity and four studies reported the reliability of dietary intake measures. Only three studies were classified as high quality (references 41, 53 and 76). Results are reported for each dietary outcome separately in Tables 2-4.

\section{Children's fruit and fruit juice intake}

Twenty-four family correlates were identified in association with children's fruit and juice consumption (see Table 2).

\section{Physical factors}

Four physical factors were identified, two of these were studied three or more times. Availability of fruit was positively associated with children's fruit consumption in five samples, and unrelated to juice consumption in two samples and fruit consumption in one sample. Accessibility of fruit was inversely associated with fruit consumption in one sample and juice in one sample and was unrelated to fruit in two samples and juice in one sample.

\section{Sociocultural factors}

Sixteen sociocultural factors were identified, with five of these studied three or more times. Parental modelling was positively associated with children's fruit consumption in five samples, positively associated with children's juice consumption in one sample and unrelated to children's fruit consumption in two samples. Parental intake was positively associated with children's fruit consumption in all three samples as well as with children's juice consumption in one sample.

Family rules (demand/allow: whether parents demand that their child eat fruit and vegetables or allow their child to eat as much fruit and vegetables as they like) were positively associated with children's fruit consumption in three out of three samples. Parental encouragement was positively associated with children's fruit consumption in three out of three samples. Frequency of family dinner was positively associated with children's juice consumption in one sample and was unrelated to children's fruit consumption in three samples.

\section{Demographic factors}

Four demographic factors were identified, with only two studied three or more times. Household income was unrelated to children's fruit consumption in two samples, unrelated to children's juice consumption in one sample and positively associated with children's fruit and juice consumption in one sample. Socio-economic status was unrelated to children's fruit consumption in three out of three samples.

\section{Children's vegetable intake}

Thirty-one family correlates were identified in association with children's vegetable intake (see Table 3 ).

\section{Physical factors}

Five physical factors were identified, two of which were studied three or more times. Availability of vegetables was positively associated with children's vegetable consumption in six out of nine samples and unrelated in three. Availability was unrelated to children's vegetable consumption in two out of three samples and positively associated with children's vegetable consumption in one.

\section{Sociocultural factors}

Twenty-one sociocultural factors were identified, eight of which were studied three or more times. Parental modelling was positively associated with children's vegetable consumption in five out of ten samples and unrelated in five. Parent intake was positively associated with children's vegetable consumption in one sample from three and unrelated in two. Family rules (demand/allow) were positively associated with children's vegetable consumption in all three samples. Parental encouragement was positively associated with children's vegetable consumption in four out of five samples.

Regarding children's vegetable consumption, frequency of family dinner was unrelated in two samples from three and positively associated in the other sample. Pressure to eat was unrelated to children's vegetable consumption in two out of three samples and positively associated in the other sample, while restriction was unrelated in three out of three samples. Family facilitation (whether parents facilitate intake of fruit and vegetables by cutting them for their child) was positively associated with children's vegetable consumption in two out of four samples and unrelated in two.

\section{Demographic factors}

Five demographic factors were identified, two of which were studied three or more times. Socio-economic status was unrelated to children's vegetable consumption in three out of four samples. Household income was unrelated to children's vegetable consumption in all three samples.

\section{Children's fruit, fruit juice and vegetable intake (FJV composite measures)}

Twenty-three family correlates were identified in association with children's FJV consumption. No demographic factors were studied three or more times (see Table 4). 
Table 2 Family correlates of children's (6-11 years) fruit consumption

\begin{tabular}{|c|c|c|c|c|c|c|c|}
\hline \multirow[b]{2}{*}{ Correlate } & \multirow{2}{*}{$\frac{\text { Related to dietary behaviours }}{\text { References }}$} & \multirow[b]{2}{*}{ Association $(+/-)$} & \multirow{2}{*}{$\frac{\text { Unrelated to dietary behaviours }}{\text { References }}$} & \multirow[b]{2}{*}{ No. of samples } & \multicolumn{3}{|c|}{ Summary $(n)$} \\
\hline & & & & & + & - & 0 \\
\hline \multicolumn{8}{|l|}{ Physical } \\
\hline Availability & [37 fruit, 53, 67, $76 \mathrm{~B} / \mathrm{G}$ ] & + & [35 G fruit, juice, 37 juice] & 6 & $5^{\star}$ & 0 & $3^{*}$ \\
\hline Accessibility & [35 G juice, 67] & - & [35 G fruit, 37 fruit, juice] & 3 & 0 & $2^{*}$ & $3^{*}$ \\
\hline Availability and accessibility & [48] & + & & 1 & 1 & 0 & 0 \\
\hline TV on during meals & & & [34 fruit, juice] & 1 & 0 & 0 & $2^{*}$ \\
\hline \multicolumn{8}{|l|}{ Sociocultural } \\
\hline Parent modelling & [37 fruit, juice, 53, 67, $76 \mathrm{~B} / \mathrm{G}$ ] & + & [61 III] & 7 & $6^{*}$ & 0 & 2 \\
\hline Parent intake & [44 M, $56 \mathrm{M}$ fruit, juice, 67] & + & & 3 & $4^{*}$ & 0 & 0 \\
\hline Maternal liking of fruit & & & [44] & 1 & 0 & 0 & 1 \\
\hline Parental control & [37 juice] & + & [37 fruit] & 1 & $1^{*}$ & 0 & $1^{*}$ \\
\hline Pressure to eat & & & {$\left[\begin{array}{lllllllllllll}61 & \mathrm{I}\end{array}\right]$} & 2 & 0 & 0 & 2 \\
\hline Restriction & & & 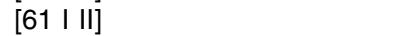 & 2 & 0 & 0 & 2 \\
\hline Family rules (demand/allow) & {$[53,76 \mathrm{~B} / \mathrm{G}]$} & + & & 3 & 3 & 0 & 0 \\
\hline Parental encouragement & {$[53,76 \mathrm{~B} / \mathrm{G}]$} & + & & 3 & 3 & 0 & 0 \\
\hline Parental facilitation & {$[76 \mathrm{~B}]$} & + & [76 G] & 2 & 1 & 0 & 1 \\
\hline Frequency of family breakfast & {$[27 \mathrm{~B} / \mathrm{G}]$} & + & & 2 & 2 & 0 & 0 \\
\hline Frequency of family dinner & [46 juice] & + & [27 B/G, 46 fruit] & 3 & $1^{*}$ & 0 & $3^{*}$ \\
\hline Maternal nutritional knowledge & [44] & + & & 1 & 1 & 0 & 0 \\
\hline Parental attitudes/beliefs & [44] & + & & 1 & 1 & 0 & 0 \\
\hline $\begin{array}{l}\text { Parental attitudes about making healthful } \\
\text { food available }\end{array}$ & {$\left[\begin{array}{ll}61 & 1\end{array}\right]$} & + & {$[61 \mathrm{II}]$} & 2 & 1 & 0 & 1 \\
\hline High- and low-fat food practices & & & [35 G fruit, juice] & 1 & 0 & 0 & $2^{*}$ \\
\hline Family type (two parents) & & & [34 fruit, juice] & 1 & 0 & 0 & $2^{*}$ \\
\hline \multicolumn{8}{|l|}{ Demographic } \\
\hline Household education & [44] & + & [35 G fruit, juice] & 2 & 1 & 0 & $2^{*}$ \\
\hline Household income & [34 fruit, juice] & + & {$[28,35 \mathrm{G}$ fruit, juice $]$} & 3 & $2^{*}$ & 0 & $3^{*}$ \\
\hline Deprivation scale & [44] & - & & 1 & 0 & 1 & 0 \\
\hline Socio-economic status & & & [46 fruit, juice, 53 M F] & 3 & 0 & 0 & $4^{*}$ \\
\hline
\end{tabular}

G, girls only; B, boys only; B/G, boys and girls analysed separately; M, mother; F, father.

For reference $61, I=$ sample of children from food-secure households; II = sample of children from food-insecure households.

References: See Table 1.
${ }^{*}$ If in one study, a correlate is examined in relation to two outcomes (e.g. fruit and juice) and the results differ for the outcomes (e.g. a positive $(+)$ association was found for fruit and no (0) association was found for juice), the study is counted once in the 'No. of samples' column, and twice in the 'Summary' column. 
Table 3 Family correlates of children's (6-11 years) vegetable consumption

\begin{tabular}{|c|c|c|c|c|c|c|c|}
\hline \multirow[b]{2}{*}{ Correlate } & \multirow{2}{*}{$\frac{\text { Related to dietary behaviours }}{\text { References }}$} & \multirow[b]{2}{*}{ Association (+/-) } & \multirow{2}{*}{$\frac{\text { Unrelated to dietary behaviours }}{\text { References }}$} & \multirow[b]{2}{*}{ No. of samples } & \multicolumn{3}{|c|}{ Summary $(n)$} \\
\hline & & & & & + & - & 0 \\
\hline \multicolumn{8}{|l|}{ Physical } \\
\hline Availability & {$[37,41 \mathrm{~B}$ II, 53, 67, $76 \mathrm{~B} / \mathrm{G}]$} & + & {$[33,35 \mathrm{G}, 41 \mathrm{~B} \mathrm{I}]$} & 9 & 6 & 0 & 3 \\
\hline Accessibility & [67] & + & {$[35 \mathrm{G}, 37]$} & 3 & 1 & 0 & 2 \\
\hline Availability and accessibility & {$[48]$} & + & & 1 & 1 & 0 & 0 \\
\hline Mealtime interruptions & & & [33] & 1 & 0 & 0 & 1 \\
\hline TV on during meals & [34] & - & & 1 & 0 & 1 & 0 \\
\hline \multicolumn{8}{|l|}{ Sociocultural } \\
\hline Parent modelling & {$[33,53,67,76 \mathrm{~B} / \mathrm{G}]$} & + & {$[37,41 \mathrm{~B} \mid \mathrm{II}, 61 \mathrm{III}]$} & 10 & 5 & 0 & 5 \\
\hline Parent intake & [67] & + & {$[44 \mathrm{M}, 56 \mathrm{M}]$} & 3 & 1 & 0 & 2 \\
\hline Mother's liking for food type & & & [44] & 1 & 0 & 0 & 1 \\
\hline $\begin{array}{l}\text { Parental positive perceptions of the adequacy } \\
\text { of child's diet }\end{array}$ & [33] & - & & 1 & 0 & 1 & 0 \\
\hline Family rules (demand/allow) & {$[53,76 \mathrm{~B} / \mathrm{G}]$} & + & & 3 & 3 & 0 & 0 \\
\hline Parental control & & & [37] & 1 & 0 & 0 & 1 \\
\hline Pressure to eat & [61 I I ] & + & {$[33,61 \mathrm{II}]$} & 3 & 1 & 0 & 2 \\
\hline Restriction & & & {$[33,61 \mid I I]$} & 3 & 0 & 0 & 3 \\
\hline Family facilitation & {$[76 \mathrm{~B} / \mathrm{G}]$} & + & [41 B I II] & 4 & 2 & 0 & 2 \\
\hline Parental monitoring & & & [33] & 1 & 0 & 0 & 1 \\
\hline Parental encouragement & [41 B II, 53, 76 B/G] & + & [41 B I] & 5 & 4 & 0 & 1 \\
\hline Frequency of family breakfast & [27 B] & + & {$[27 \mathrm{G}]$} & 2 & 1 & 0 & 1 \\
\hline Frequency of family dinner & [27 G] & + & {$[46,27 \mathrm{~B}]$} & 3 & 1 & 0 & 2 \\
\hline Mother's concern for child's taste preferences & & & [44] & 1 & 0 & 0 & 1 \\
\hline Maternal nutritional knowledge & & & [44] & 1 & 0 & 0 & 1 \\
\hline Parenting attitudes about making healthful food available & & & {$\left[\begin{array}{llll}61 & \mathrm{I} & \mathrm{II}\end{array}\right]$} & 2 & 0 & 0 & 2 \\
\hline $\begin{array}{l}\text { Mother's attitude to fruit and vegetables and child's } \\
\text { cancer risk }\end{array}$ & & & [44] & 1 & 0 & 0 & 1 \\
\hline $\begin{array}{l}\text { Mother's concern for disease prevention in choosing } \\
\text { child's diet }\end{array}$ & [44] & - & & 1 & 0 & 1 & 0 \\
\hline High- and low-fat food practices & & & [35 G] & 1 & 0 & 0 & 1 \\
\hline Family type (two parents) & & & [34] & 1 & 0 & 0 & 1 \\
\hline Family type (one parent) & [77] & - & & 1 & 0 & 1 & 0 \\
\hline \multicolumn{8}{|l|}{ Demographic } \\
\hline Household education & & & {$[35 \mathrm{G}, 44 \mathrm{M}]$} & 2 & 0 & 0 & 2 \\
\hline Household income & & & {$[28,34,35 \mathrm{G}]$} & 3 & 0 & 0 & 3 \\
\hline Deprivation scale & & & [44] & 1 & 0 & 0 & 1 \\
\hline Number of hours worked by mother & & & {$[34,77]$} & 2 & 0 & 0 & 2 \\
\hline Socio-economic status & [46] & + & [53 M F, 77] & 4 & 1 & 0 & 3 \\
\hline
\end{tabular}
G, girls only; B, boys only; B/G, boys and girls analysed separately; M, mother; $F$, father.
For reference $41, I=$ sample of normal weight children, II = sample of overweight children; for reference $61, I=$ sample of children from food-secure households, II = sample of children from food-insecure households. References: See Table 1. 
Table 4 Family correlates of children's (6-11 years) fruit, fruit juice and vegetable (FJV) consumption

\begin{tabular}{|c|c|c|c|c|c|c|c|}
\hline \multirow[b]{2}{*}{ Correlate } & \multirow{2}{*}{$\frac{\text { Related to dietary behaviours }}{\text { References }}$} & \multirow[b]{2}{*}{ Association (+/-) } & \multirow{2}{*}{$\frac{\text { Unrelated to dietary behaviours }}{\text { References }}$} & \multirow[b]{2}{*}{ No. of samples } & \multicolumn{3}{|c|}{ Summary $(n)$} \\
\hline & & & & & + & - & 0 \\
\hline \multicolumn{8}{|l|}{ Physical } \\
\hline Availability & {$[36 \mathrm{G}, 37]$} & + & {$[36 \mathrm{~B}, 38]$} & 4 & 2 & 0 & 2 \\
\hline Accessibility & {$[30 \mathrm{I}, 31,36 \mathrm{G}]$} & + & {$[36 \mathrm{~B}, 37,38]$} & 6 & 3 & 0 & 3 \\
\hline Changes in accessibility & {$[30 \mathrm{II}]$} & + & & 1 & 1 & 0 & 0 \\
\hline Availability and accessibility & [48] & + & & 1 & 0 & & 0 \\
\hline \multicolumn{8}{|l|}{ Sociocultural } \\
\hline Parent modelling & {$[30 \mathrm{I}, 31,37]$} & + & & 3 & 3 & 0 & 0 \\
\hline Changes in parental modelling & [30 II] & + & & 1 & 1 & 0 & 0 \\
\hline Parent intake & {$[26,31]$} & + & [42 G] & 3 & 2 & 0 & 1 \\
\hline Parent intake if FV are highly available & [51] & + & & 1 & 1 & 0 & 0 \\
\hline Parent intake if FV are low available & & & [51] & 1 & 0 & 0 & 1 \\
\hline Negative parenting style & [38] & - & & 1 & 0 & 1 & 0 \\
\hline Authoritative parenting style & & & [38] & 1 & 0 & 0 & 1 \\
\hline Encouragement/verbal praise & & & [38] & 1 & 0 & 0 & 1 \\
\hline Parental control & & & [37] & 1 & 0 & 0 & 1 \\
\hline Control/restriction & & & [38] & 1 & 0 & 0 & 1 \\
\hline Family expressiveness & & & {$[42 \mathrm{G}]$} & 1 & 0 & 0 & 1 \\
\hline Frequency of family meals & & & {$[42 \mathrm{G}]$} & 1 & 0 & 0 & 1 \\
\hline Parental food preparation practices & & & [38] & 1 & 0 & 0 & 1 \\
\hline Single-parent family & [62 II] & + & [62 I] & 2 & 1 & 0 & 1 \\
\hline Household size & & & [26] & 1 & 0 & 0 & 1 \\
\hline \multicolumn{8}{|l|}{ Demographic } \\
\hline Household socio-economic status & [62 II] & - & [62 I] & 2 & 0 & 1 & 1 \\
\hline Socio-economic deprivation & {$[75 \mathrm{G}]$} & - & {$[75$ B] } & 2 & 0 & 1 & 1 \\
\hline Parental education & & & [26] & 1 & 0 & 0 & 1 \\
\hline Parental marital status & & & [26] & 1 & 0 & 0 & 1 \\
\hline
\end{tabular}

G, girls only; B, boys only; B/G, boys and girls analysed separately; M, mother; F, father.

For reference 30 (prospective study), I = sample at beaseline, II = sample at follow-up. For reference $62, \mathrm{I}=$ sample of second grade children, II = sample of fifth grade children.

References: See Table 1. 


\section{Physical factors}

Four physical factors were identified and two were studied three or more times. Availability of FJV was positively associated with children's FJV consumption in two out of four samples and unrelated in the other two. Accessibility was also positively associated with children's FJV consumption in three out of six samples and unrelated in three.

\section{Sociocultural factors}

Fifteen sociocultural factors were identified, and only two were studied three or more times. Parental modelling was positively associated with children's FJV in three out of three samples. Parent intake was positively associated with children's FJV consumption in two out of three samples.

\section{Family correlates of adolescents' dietary intake}

Thirty-eight studies (fifty-five samples) of adolescents were reviewed (see Table 1 ). The majority of studies were conducted in the USA ( $n$ 17). Twenty studies examined associations between family correlates and dietary outcomes for boys and girls combined, seventeen examined associations separately for boys and girls and one investigated associations for boys only. The majority used a cross-sectional design ( $n$ 35), and assessed dietary outcomes through self-report ( $n$ 33), using FFQ ( $n$ 25), and had a large average sample size (range $=50-114558$; mean $n$ 6547). Only two studies reported the validity and six studies the reliability of the dietary intake measures used. Only four studies were classified as high quality (references 47, 54, 65 and 85). Results are reported for each dietary outcome separately in Tables 5-7.

\section{Adolescents' fruit and juice intake}

Thirty-four family correlates were identified in association with adolescents' fruit and juice consumption (see Table 5).

\section{Physical factors}

Four physical factors were identified, with only one studied three or more times. Availability of fruit was unrelated to adolescents' fruit consumption in two samples, unrelated to adolescents' juice consumption in one sample and was positively associated with adolescents' fruit consumption in two samples.

\section{Sociocultural factors}

Twenty-four sociocultural factors were identified, with only two studied three or more times. Parent intake of fruit was positively associated with adolescents' fruit consumption in three out of four samples. Food rules were unrelated to adolescents' fruit consumption in three samples and positively associated in one sample.

\section{Demographic factors}

Six demographic factors were identified, with four studied three or more times. Parental education was unrelated to adolescents' fruit consumption in five out of ten samples and positively associated in the other five. Household income was positively associated with adolescents' fruit consumption in four samples from eight, inversely associated in one sample and unrelated in the other three. All six samples found a positive association between occupational status and adolescents' fruit consumption. Socioeconomic index was inversely associated with fruit and juice consumption in one sample, positively associated with fruit consumption in four samples and unrelated to adolescents' fruit consumption in two samples and juice consumption in one sample.

\section{Adolescents' vegetable intake}

Twenty-nine family correlates were identified in association with adolescents' vegetable consumption (see Table 6).

\section{Physical factors}

One physical factor (availability of vegetables) was identified and was studied four times. It was unrelated to adolescents' vegetable consumption in three samples and was positively associated in the other.

\section{Sociocultural factors}

Twenty-two sociocultural factors were identified, and two of these were studied three or more times. Parental intake was positively associated with adolescents' vegetable consumption in three out of four samples. Frequency of family meals was unrelated to adolescents' vegetable consumption in three out of four samples.

\section{Demographic factors}

Six demographic factors were identified, four of these being studied three or more times. Parental education was unrelated to adolescents' vegetable consumption in eight out of twelve samples and positively associated in the other four. Household income was unrelated to adolescents' vegetable consumption in all nine samples, while parental occupation was unrelated in five out of seven samples. Socio-economic status was unrelated to adolescents' vegetable consumption in three out of five samples.

\section{Adolescents' fruit, fruit juice and vegetable intake (FJV composite measures)}

Twenty-three family correlates were identified in association with adolescents' FJV consumption. No physical factors were studied three or more times (see Table 7).

\section{Sociocultural factors}

Eighteen sociocultural factors were identified, and three were studied three or more times. Authoritative parenting style was unrelated to adolescents' FJV consumption in two out of three samples. Parental monitoring was unrelated to adolescents' FJV consumption in two out of three samples. Family size was unrelated to adolescents' FJV consumption in all three samples. 
Table 5 Family correlates of adolescents' (12-18 years) fruit consumption

\begin{tabular}{|c|c|c|c|c|c|c|c|}
\hline \multirow[b]{2}{*}{ Correlate } & \multirow{2}{*}{$\begin{array}{c}\text { Related to dietary behaviours } \\
\text { References }\end{array}$} & \multirow[b]{2}{*}{ Association $(+/-)$} & \multirow{2}{*}{$\begin{array}{c}\text { Unrelated to dietary behaviours } \\
\text { References }\end{array}$} & \multirow[b]{2}{*}{ No. of samples } & \multicolumn{3}{|c|}{ Summary $(n)$} \\
\hline & & & & & + & - & 0 \\
\hline \multicolumn{8}{|l|}{ Physical } \\
\hline Availability & {$[29,47 \mathrm{G}]$} & + & [43 B fruit, juice, $47 \mathrm{G}$ ] & 4 & 2 & 0 & $3+$ \\
\hline Availability of unhealthy foods & & & {$[85 \mathrm{~B} / \mathrm{G}]$} & 2 & 0 & 0 & 2 \\
\hline Availability of healthy foods & [85 G] & + & {$[85 \mathrm{~B}]$} & 2 & 1 & 0 & 1 \\
\hline Availability and accessibility & & & {$[60]$} & 1 & 0 & 0 & 1 \\
\hline \multicolumn{8}{|l|}{ Sociocultural } \\
\hline Parent modelling & [40 subjective*] & + & [40 objective*] & 1 & $1 \ddagger$ & 0 & $1 \neq$ \\
\hline Parent intake & {$[39 \mathrm{~B} / \mathrm{G}, 47 \mathrm{G}]$} & + & {$[47 \mathrm{~B}]$} & 4 & 3 & 0 & 1 \\
\hline Perceived parental intake & & & {$[60]$} & 1 & 0 & 0 & 1 \\
\hline Parenting style (authoritative) & [52] & + & & 1 & 1 & 0 & 0 \\
\hline Parental control on food choice & & & [74] & 1 & 0 & 0 & 1 \\
\hline Parental presence before and after school & & & [74] & 1 & 0 & 0 & 1 \\
\hline Food rules & [85 G] & + & [ 40 objective, subjective, $60,85 \mathrm{~B}]$ & 4 & 1 & 0 & $4 \ddagger$ \\
\hline Family food routines & & & [40 objective, subjective] & 1 & 0 & 0 & $2 \ddagger$ \\
\hline Social support & & & [60] & 1 & 0 & 0 & 1 \\
\hline Number of evening meals eaten with parent present & [74] & + & & 1 & 1 & 0 & 0 \\
\hline Frequency of family meals & {$[29,63]$} & + & & 2 & 2 & 0 & 0 \\
\hline Frequency of family breakfast & & & [27 B/G] & 2 & 0 & 0 & 2 \\
\hline Frequency of family dinner & & & [27 B/G] & 2 & 0 & 0 & 2 \\
\hline Fast food bought for family meals & & & [32] & 1 & 0 & 0 & 1 \\
\hline Frequency of food shopping & & & {$[54 \mathrm{~B} / \mathrm{G}]$} & 2 & 0 & 0 & 2 \\
\hline Health food is asked for (shopping) & [40 objective, subjective] & + & & 1 & $2 \ddagger$ & 0 & 0 \\
\hline Food asked for (shopping) is bought & [40 objective, subjective] & - & & 1 & 0 & $2 \ddagger$ & 0 \\
\hline Shopping alone/family & & & [40 objective, subjective] & 1 & 0 & 0 & $2 \ddagger$ \\
\hline Helping to prepare food for dinner & {$[54 \mathrm{~B} / \mathrm{G}]$} & + & & 2 & 2 & 0 & 0 \\
\hline Family connectedness & {$[64,70]$} & + & & 2 & 2 & 0 & 0 \\
\hline Parent-child interactions & & & [40 objective, subjective] & 1 & 0 & 0 & $2 \ddagger$ \\
\hline Negative communication strategies & & & [40 objective, subjective] & 1 & 0 & 0 & $2 \ddagger$ \\
\hline Family size & & & {$[79 \mathrm{~B} / \mathrm{G}]$} & 2 & 0 & 0 & 2 \\
\hline Residence with family & [71 summer fruit] & - & [71 winter fruit, juice] & 2 & 0 & 1 & $2 \dagger$ \\
\hline \multicolumn{8}{|l|}{ Demographic } \\
\hline Parental education & [59 G M, 66 M F, 74, 81] & + & [39 B/G M, 59 B M, 79 B/G] & 10 & 5 & 0 & 5 \\
\hline Household income & {$[28 \mathrm{~B} / \mathrm{G}, 39 \mathrm{~B} / \mathrm{G}, 45 \mathrm{~B}]$} &,,++- & [43 B fruit, juice, $45 \mathrm{G}, 81$ ] & 8 & 4 & 1 & $4 \dagger$ \\
\hline Family material wealth & [72] & + & & 1 & 1 & 0 & 0 \\
\hline Occupational class & [71 fruit, juice] & + & & 1 & $2+$ & 0 & 0 \\
\hline Occupational status & {$[66 \mathrm{~F}, 72,73 \mathrm{~B} / \mathrm{G}, 79 \mathrm{~B} / \mathrm{G}]$} & + & & 6 & 6 & 0 & 0 \\
\hline Socio-economic status & [49 G fruit, juice, $64,69 \mathrm{~B} / \mathrm{G}, 85 \mathrm{G}$ ] &,,,-+++ & [49 B fruit, juice, 85 B] & 7 & 4 & $2+$ & $3+$ \\
\hline
\end{tabular}

G, girls only; B, boys only; B/G, boys and girls analysed separately; M, mother; $F$, father.

References: See Table 1.

evaluation of 'objective' food frequency questionnaire scores; Objective = food frequency questionnaire.

tIf in one study, a correlate is examined in relation to two outcomes (e.g. fruit and juice) and the results differ for the outcomes (e.g. a positive $(+)$ association was found for fruit and no (0) association was found for juice), If in one study, a correlate

and the results differ for the outcomes (e.g. a positive $(+)$ association was found for the objective measure and no (0) association was found for the subjective measure), the study is counted once in the 'No. of samples' column and twice in the 'Summary' column. 
Table 6 Family correlates of adolescent (12-18 years) vegetable consumption

\begin{tabular}{|c|c|c|c|c|c|c|c|}
\hline \multirow[b]{2}{*}{ Correlate } & \multirow{2}{*}{$\frac{\text { Related to dietary behaviours }}{\text { References }}$} & \multirow[b]{2}{*}{ Association $(+/-)$} & \multirow{2}{*}{$\begin{array}{c}\text { Unrelated to dietary behaviours } \\
\text { References }\end{array}$} & \multirow[b]{2}{*}{ No. of samples } & \multicolumn{3}{|c|}{ Summary $(n)$} \\
\hline & & & & & + & - & 0 \\
\hline \multicolumn{8}{|l|}{ Physical } \\
\hline Availability & [47 G] & + & {$[29,43 \mathrm{~B}, 47 \mathrm{~B}]$} & 4 & 1 & 0 & 3 \\
\hline \multicolumn{8}{|l|}{ Sociocultural } \\
\hline Parent modelling & & & {$\left[40\right.$ objective $^{\star}$, subjective $\left.^{\star}\right]$} & 1 & 0 & 0 & $2 \dagger$ \\
\hline Parent intake & {$[39 \mathrm{~B} / \mathrm{G}, 47 \mathrm{G}]$} & + & {$[47 \mathrm{~B}]$} & 4 & 3 & 0 & 1 \\
\hline Food rules & & & [40 objective, subjective] & 1 & 0 & 0 & $2 \dagger$ \\
\hline Family food routines & & & [40 objective, subjective] & 1 & 0 & 0 & $2+$ \\
\hline Parental control on food choice & & & [74] & 1 & 0 & 0 & 1 \\
\hline Parental presence before and after school & & & [74] & 1 & 0 & 0 & 1 \\
\hline Family connectedness & {$[64,70]$} & + & & 2 & 2 & 0 & 0 \\
\hline $\begin{array}{l}\text { Number of evening meals eaten with } \\
\text { parent present }\end{array}$ & [74] & + & & 1 & 1 & 0 & 0 \\
\hline Frequency of family meals & [63] & + & {$[29,68 \mathrm{~B} / \mathrm{G}]$} & 4 & 1 & 0 & 3 \\
\hline Frequency of family breakfast & & & {$[27 \mathrm{~B} / \mathrm{G}]$} & 2 & 0 & 0 & 2 \\
\hline Frequency of family dinner & [27 G] & + & {$[27 \mathrm{~B}]$} & 2 & 1 & 0 & 1 \\
\hline Fast food bought for family meals & & & [32] & 1 & 0 & 0 & 1 \\
\hline Frequency of food shopping & & & {$[54 \mathrm{~B} / \mathrm{G}]$} & 2 & 0 & 0 & 2 \\
\hline Health food is asked for (shopping) & & & [40 objective, subjective] & 1 & 0 & 0 & $2+$ \\
\hline Food asked for (shopping) is bought & [40 objective] & - & [40 subjective] & 1 & 0 & $1+$ & $1+$ \\
\hline Shopping alone/family & & & [40 objective, subjective] & 1 & 0 & 0 & $2+$ \\
\hline Helping to prepare food for dinner & {$[54 \mathrm{G}]$} & + & [54 B] & 2 & 1 & 0 & 1 \\
\hline Negative communication strategies & [40 objective] & - & [40 subjective] & 1 & 0 & $1+$ & $1+$ \\
\hline Parent-child interactions & [40 subjective] & + & [40 objective] & 1 & $1+$ & 0 & $1+$ \\
\hline Family type (two parents) & & & {$[68 \mathrm{~B} / \mathrm{G}]$} & 2 & 0 & 0 & 2 \\
\hline Family size & & & {$[79 \mathrm{~B} / \mathrm{G}]$} & 2 & 0 & 0 & 2 \\
\hline Residence with family & & & [71] & 1 & 0 & 0 & 1 \\
\hline \multicolumn{8}{|l|}{ Demographic } \\
\hline Parent education & {$[66 \mathrm{M}, 74,79 \mathrm{G} \mathrm{M}, 81]$} & + & $\begin{array}{l}\text { [39 B/G M, } 59 \text { B/G M, } 66 \text { F, } 79 \text { G F, } \\
79 \text { B M F] }\end{array}$ & 12 & 4 & 0 & 8 \\
\hline Household education & [68 B/G] & + & & 2 & 2 & 0 & 0 \\
\hline Household income & & & [28 B/G, $39 \mathrm{~B} / \mathrm{G}, 43 \mathrm{~B}, 45 \mathrm{~B} / \mathrm{G}, 68,81]$ & 9 & 0 & 0 & 9 \\
\hline Parental occupation & {$[73 \mathrm{~B} / \mathrm{G}]$} & + & {$[66 \mathrm{~F}, 68 \mathrm{~B} / \mathrm{G}, 79 \mathrm{~B} / \mathrm{G}]$} & 7 & 2 & 0 & 5 \\
\hline Occupational class & [71] & + & & 1 & 1 & 0 & 0 \\
\hline Socio-economic status & {$[49 \mathrm{~B}, 64]$} & + & [49 G, $69 \mathrm{~B} / \mathrm{G}]$ & 5 & 2 & 0 & 3 \\
\hline
\end{tabular}

G, girls only; B, boys only; B/G, boys and girls analysed separately; M, mother; $F$, father.

References: See Table 1.

'Subjective = evaluation of 'objective' food frequency questionnaire scores; Objective = food frequency questionnaire.

If in one study, a correlate is examined by two methods (e.g. objectively and subjectively) and the results differ for the outcomes (e.g. a positive ( + ) association was found for the objective measure and no (0) association was found for the subjective measure), the study is counted once in the 'No. of samples' column and twice in the 'Summary' column. 
Table 7 Family correlates of adolescents' (12-18 years) fruit, fruit juice and vegetable (FJV) consumption

\begin{tabular}{|c|c|c|c|c|c|c|c|}
\hline \multirow[b]{2}{*}{ Correlate } & \multirow{2}{*}{$\frac{\text { Related to dietary behaviours }}{\text { References }}$} & \multirow[b]{2}{*}{ Association $(+/-)$} & \multirow{2}{*}{$\frac{\text { Unrelated to dietary behaviours }}{\text { References }}$} & \multirow[b]{2}{*}{ No. of samples } & \multicolumn{3}{|c|}{ Summary $(n)$} \\
\hline & & & & & + & - & 0 \\
\hline \multicolumn{8}{|l|}{ Physical } \\
\hline Availability & {$[65,83]$} & + & & 2 & 2 & 0 & 0 \\
\hline \multicolumn{8}{|l|}{ Sociocultural } \\
\hline Parent modelling & [83] & + & & 1 & 1 & 0 & 0 \\
\hline Parent intake & {$[26]$} & + & & 1 & 1 & 0 & 0 \\
\hline Perceived parental intake & {$[80]$} & + & & 1 & 1 & 0 & 0 \\
\hline Parenting style (authoritative) & {$[58 \mathrm{M}]$} & + & [58 F, 83] & 3 & 1 & 0 & 2 \\
\hline Parenting style (non-authoritative) & {$[58 \mathrm{~F}]$} & + & {$[58 \mathrm{M}]$} & 2 & 1 & 0 & 1 \\
\hline Parental presence before/on return from school & & & [82] & 1 & 0 & 0 & 1 \\
\hline Perceived parental evaluation of his/her diet & {$[55 \mathrm{~B} / \mathrm{G}]$} & + & & 2 & 2 & 0 & 0 \\
\hline Parents physically active & & & [55 B/G] & 2 & 0 & 0 & 2 \\
\hline Parental monitoring & [82] & + & {$[55 \mathrm{~B} / \mathrm{G}]$} & 3 & 1 & 0 & 2 \\
\hline Parental control & & & [83] & 1 & 0 & 0 & 1 \\
\hline Family influence (encouragement to eat FV/provided FV) & {$[84 \mathrm{G}]$} & + & {$[84 \mathrm{~B}]$} & 2 & 1 & 0 & 1 \\
\hline Parental support & [83] & + & & 1 & 1 & 0 & 0 \\
\hline Healthful household rules & [84 B] & + & {$[84 \mathrm{G}]$} & 2 & 1 & 0 & 1 \\
\hline Family support & & & {$[84 \mathrm{~B} / \mathrm{G}]$} & 2 & 0 & 0 & 2 \\
\hline Family communication & [82] & + & & 1 & 1 & 0 & 0 \\
\hline Positive relations with parents & {$[55 \mathrm{~B} / \mathrm{G}]$} & + & & 2 & 2 & 0 & 0 \\
\hline Family size & & & {$[26,78 \mathrm{~B} / \mathrm{G}]$} & 3 & 0 & 0 & 3 \\
\hline Family type & & & {$[50,82]$} & 2 & 0 & 0 & 2 \\
\hline \multicolumn{8}{|l|}{ Demographic } \\
\hline Parental education & {$[50 \mathrm{M}, 55 \mathrm{~B} / \mathrm{G}, 57 \mathrm{~B} / \mathrm{G}, 58]$} & + & {$[26,78 \mathrm{~B} / \mathrm{G}]$} & 9 & 6 & 0 & 3 \\
\hline Parental marital status & & & [26] & 1 & 0 & 0 & 1 \\
\hline Family income & & & {$[57 \mathrm{~B} / \mathrm{G}]$} & 2 & 0 & 0 & 2 \\
\hline Socio-economic status & & & {$[78 \mathrm{~B} / \mathrm{G}]$} & 2 & 0 & 0 & 2 \\
\hline
\end{tabular}

G, girls only; B, boys only; B/G, boys and girls analysed separately; M, mother; F, father.

References: See Table 1. 


\section{Demographic factors}

Four demographic factors were identified, and one was studied three or more times. Parental education was positively associated with adolescent FJV consumption in six out of nine samples and unrelated in the other three.

\section{Discussion}

The purpose of the present review was to evaluate the published literature on family correlates of fruit and vegetable consumption in children and adolescents.

The review shows that home availability, family rules (demand/allow) and parental encouragement were positively associated with children's fruit and vegetable consumption and that parental modelling and parental intake were positively associated with children's consumption of fruit and FJV. Our findings support the work of others ${ }^{(18,19)}$ that parental intake and home availability are strongly related to children's eating behaviours. The importance of parental intake, parental modelling and home availability on children's food consumption is also supported by the qualitative work of Campbell et al. ${ }^{(23)}$ who found that parents believed eating with their children was important in order to model eating behaviours and also that making food available was likely to influence child's food consumption.

Parental intake and parental occupational status were found to be positively associated with adolescents' consumption of fruit. Parental intake was also positively associated with adolescents' vegetable consumption. There is also evidence for a positive association between parental education and adolescents' FJV consumption. Our findings support the work of others ${ }^{(18,19)}$ that parental intake is strongly related to adolescents' eating behaviours. The importance of parental intake on adolescents' fruit and vegetable consumption is also supported by the qualitative work of Kubik et $a l .{ }^{(24)}$ who found that adolescents' reported eating whatever their parents ate.

The positive association between parental occupational status and adolescents' fruit consumption was expected and supports the work of Dowler et al. ${ }^{(25)}$ who have found that people in poorer households are less likely to eat fresh fruit and other more healthy foods. However, socio-economic status (measured in diverse ways) has been examined in a large number of studies in association with adolescents' fruit, vegetable and FJV consumption and associations were either not evident or were indeterminate throughout the dietary behaviours investigated, indicating that the association between poorer households and healthy eating is not so clear. That parental occupation and parental education were positively associated with adolescents' fruit and FJV consumption, respectively, suggest that for adolescents, family circumstance factors may be a more important influence on dietary behaviours than sociocultural factors, and indeed may modify the association between sociocultural factors and dietary behaviours.

This is the first review of its kind to analyse family correlates of fruit, vegetables and FJV separately, distinguish findings for children and adolescents separately, and to examine correlates individually. In previous work, such behaviours and age groups have been examined together and correlates that were conceptually similar were combined, limiting the depth of analysis. The present review offers new insight into the family influences on these specific behaviours among children and adolescents. More adolescent studies exist in the literature than studies of children (thirty-eight compared with twenty-five). Only three studies ${ }^{(26-28)}$ investigated both children and adolescents and found differences in results for the two age groups. For example, Kusano-Tsunoh et $a l^{(27)}$ found that frequency of family breakfast was positively associated with fruit consumption for children but not for adolescents. Differences between these age stages are expected because adolescence is a complex time period accompanied by changes in social influences. We have found that the influence of parental intake was the only common correlate positively associated with children's and adolescents' dietary intake. This finding was expected and is consistent with previous reviews ${ }^{(18,19)}$. This finding can now be accepted as robust in young people and suggests that parental behaviours clearly play important roles in the dietary behaviours of young people.

The review also adds support to the literature for positive associations between availability and children's fruit and vegetable consumption, between parental modelling and children's fruit and FJV consumption, and new support for positive associations between family rules and parental encouragement and children's fruit and vegetable consumption. The present review also adds new support for positive associations between parental occupational status and adolescent fruit consumption, and for positive associations between parental education and adolescents' FJV consumption.

There are limitations to the present review, some of which are due to gaps in the literature itself. Studies were diverse in character (e.g. measures used and correlates studied) and so it is not possible to assess the overall consistency of associations. Several studies may not have been powered to detect significant associations between family correlates and dietary behaviours. Few studies have examined the same specific combination of family correlate and dietary behaviour, thus limiting the possibilities of drawing strong or consistent conclusions. The majority of studies reviewed were cross-sectional, making conclusions about direction and causality of associations impossible. The majority of the studies used self-report measures, and little data on the reliability and validity of measures of dietary outcomes were available. Study quality was relatively low due to many studies not reporting reliability and validity of measures used to assess physical and sociocultural family correlates. This 
could have led to measurement error and may have also been a cause of inconsistency in the results. Studies relied on self-reported or perceived family information.

Only published papers in the English language were included in the review. Strengths of the review include the systematic approach adopted and the summary of sixty published papers, the clear definitions of associations between correlates and dietary outcome by examining and reporting dietary outcomes separately, and the use of coding associations. The present review also examined and reported the results of children and adolescents separately using individual samples as units of analysis, and family correlates were not combined.

A large number of family correlates have been studied among children and adolescents, and it is clear that dietary behaviours of children and adolescents are complex and influenced by multiple factors that are, in most cases, different across age stages. There is a lack of evidence from which to draw strong conclusions on the differences in family correlates of children's and adolescents' fruit and vegetable consumption. Longitudinal studies investigating family correlates following children through to adolescence are needed. Similarly, only three of the identified studies of children examined associations for boys and girls separately. Studies should expand their analyses to include results by gender, as this may be important when tailoring interventions. A large number of associations studied between family correlates and fruit and vegetable consumption of young people were inconsistent or not replicated or provided indeterminate results. Many correlates have been studied too few times to draw any clear conclusions (e.g. parental control and family type). More studies are needed to test understudied correlates to generate more convincing evidence for associations between correlates and dietary behaviours. Studies should report the validity and reliability of measures used to assess predictor variables, in order to assess the quality of studies.

These findings highlight the importance of targeting the family environment for the promotion of healthy eating behaviours in young people. Future interventions should encourage parents to be positive role models by targeting parental intake and to create a supportive home environment through increased encouragement and availability of fruits and vegetables and employing rules to govern eating behaviours. For adolescents, indicators of family circumstance (e.g. parental education) should be used to identify target groups for interventions aimed at promoting healthy eating.

\section{Acknowledgements}

Conflict of interest: There are no conflicts of interest, financial or otherwise, that are directly relevant to the content of this review.
Author contributions: N.P. performed the literature searches, extracted and analysed the data and wrote the first draft of the review. S.J.H.B. contributed to the coding of studies and to the final draft of the review. T.G. assisted with the supervision of the first author and contributed to the final draft of the review.

\section{References}

1. World Health Organization (2002) The World Health Report. Reducing Risks, Promoting Healthy Life. Geneva: WHO.

2. Knai C, Pomerleau J, Lock K \& McKee M (2006) Getting children to eat more fruit and vegetables: a systematic review. Prev Med 42, 85-95.

3. Kelder SH, Perry CL, Klepp KI \& Lytle LL (1994) Longitudinal tracking of adolescent smoking, physical activity, and food choice behaviors. Am J Public Health 84, 1121-1126.

4. Resnicow K, Smith M, Baranowski T, Baranowski J, Vaughan R \& Davis M (1998) 2-year tracking of children's fruit and vegetable intake. J Am Diet Assoc 98, 785-789.

5. Mikkila V, Rasanen L, Raitakari OT, Pietinen P \& Viikari J (2004) Longitudinal changes in diet from childhood into adulthood with respect to risk of cardiovascular diseases: The Cardiovascular Risk in Young Finns Study. Eur J Clin Nutr 58, 1038-1045.

6. Maynard M, Gunnel D, Emmett P, Frankel S \& Davey Smith G (2003) Fruit, vegetables and antioxidants in childhood and risk of adult cancer: the Boyd Orr cohort. $J$ Epidemiol Community Health 57, 218-225.

7. Currie C, Robert C, Morgan A, Smith R, Settertobulte W, Samdal O \& Rasmussen VB (editors) (2004) Young People's Health in Context. Health Behaviour in School-aged Children (HBSC): International Report from the 2001/ 2002 Survey. Health Policy for Children and Adolescents Series no. 4. Copenhagen: WHO Regional Office for Europe.

8. Guenther PM, Dodd KW, Reedy J \& Krebs-Smith SM (2006) Most Americans eat much less than recommended amounts of fruits and vegetables. J Am Diet Assoc 106, 1371-1379.

9. Margarey A, Daniels LA \& Smith A (2001) Fruit and vegetable intakes of Australians aged 2-18 years: an evaluation of the 1995 National Nutrition Survey data. Aus N Z J Public Health 25, 155-161.

10. World Health Organization (2007) Young people's health in context: selected key findings from the Health Behaviour in School-aged Children study. Fact Sheet EURO/04/04 2004. http://www.euro.who.int/document/mediacentre/ fs0404e.pdf

11. Green LW \& Kreuter MW (1991) Health Promotion Planning: an Educational and Environmental Approach. Mountain View, CA: Myfield.

12. Parsons T \& Bales R (1956) Family, Socialization and Interaction Process. London: Routledge and Kegan Paul.

13. Tinsley BJ (2003) How Children Learn to be Healthy. Cambridge: Cambridge University Press.

14. Crockett SJ \& Sims LS (1995) Environmental influences on children's eating. J Nutr Educ 27, 235-249.

15. Patrick H \& Nicklas TA (2005) A review of family and social determinants of children's eating patterns and diet quality. J Am Coll Nutr 24, 83-92.

16. Shepherd J, Harden A, Rees R, Brunton G, Garcia J, Oliver S \& Oakley A (2006) Young people and healthy eating: a systematic review of research on barriers and facilitators. Health Educ Res 21, 239-257. 
17. Story M, Neumark-Sztainer D \& French S (2002) Individual and environmental influences on adolescent eating behaviors. J Am Diet Assoc 102, Suppl. 3, S40-S51.

18. van der Horst K, Oenema A, Ferreira I, Wendel-Vos W, Giskes K, van Lenthe F \& Brug J (2007) A systematic review of environmental correlates of obesity-related dietary behaviors in youth. Health Educ Res 22, 203-226.

19. Rasmussen M, Krolner R, Klepp KI, Lytle L, Brug J, Bere E \& Due P (2006) Determinants of fruit and vegetable consumption among children and adolescents: a review of the literature. Part I: quantitative studies. Int J Behav Nutr Phys Activity 3, 22.

20. NHS Centre for Reviews and Dissemination (2001) Undertaking Systematic Reviews of Research on Effectiveness: CRD's Guidance for Those Carrying Out or Commissioning Reviews. York: University of York.

21. Sallis JF, Prochaska JJ \& Taylor WC (2000) A review of correlates of physical activity of children and adolescents. Med Sci Sports Exerc 32, 963-975.

22. Cooper H (1998) Synthesizing Research: A Guide for Literature Reviews. London: Sage.

23. Campbell KJ, Crawford DA \& Hesketh KD (2007) Australian parents' views on their 5-6-year-old children's food choices. Health Promot Int 22, 11-18.

24. Kubik MY, Lytle L \& Fulkerson JA (2005) Fruits, vegetables, and football: findings from focus groups with alternative high school students regarding eating and physical activity. $J$ Adolesc Health 36, 494-500.

25. Dowler E, Turner S \& Dobson B (2001) Poverty Bites: Food, Health and Poor Families. London: CPAG.

26. Hannon PA, Bowen DJ, Moinpour CM \& McLerran DF (2003) Correlations in perceived food use between the family food preparer and their spouses and children. Appetite 40, 77-83.

27. Kusano-Tsunoh A, Nakatsuka $H$, Satoh $H$, Shimizu $H$, Sato S, Ito I, Fukao A \& Hisamichi S (2001) Effects of familytogetherness on the food selection by primary and junior high school students: family-togetherness means better food. Tohoku J Exp Med 194, 121-127.

28. Myres AW \& Kroetsch D (1978) The influence of family income on food consumption patterns and nutrient intake in Canada. Can J Public Health 69, 208-221.

29. Befort C, Kaur H, Nollen N, Sullivan DK, Nazir N, Choi WS, Hornberger L \& Ahluwalia JS (2006) Fruit, vegetable, and fat intake among non-Hispanic black and non-Hispanic white adolescents: associations with home availability and food consumption settings. J Am Diet Assoc 106, 367-373.

30. Bere E \& Klepp KI (2005) Changes in accessibility and preferences predict children's future fruit and vegetable intake. Int J Behav Nutr Phys Activity 2, 15.

31. Bere E \& Klepp KI (2004) Correlates of fruit and vegetable intake among Norwegian schoolchildren: parental and selfreports. Public Health Nutr 7, 991-998.

32. Boutelle KN, Fulkerson JA, Neumark-Sztainer D, Story M \& French SA (2007) Fast food for family meals: relationships with parent and adolescent food intake, home food availability and weight status. Public Health Nutr 10, $16-23$.

33. Campbell KJ, Crawford DA \& Ball K (2006) Family food environment and dietary behaviors likely to promote fatness in 5-6 year-old children. Int J Obes 30, 1272-1280.

34. Coon KA, Goldberg J, Rogers BL \& Tucker KL (2001) Relationships between use of television during meals and children's food consumption patterns. Pediatrics 107, E7.

35. Cullen KW, Baranowski T, Klesges LM, Watson K, Sherwood NE, Story M, Zakeri I, Leachman-Slawson D \& Pratt C (2004) Anthropometric, parental, and psychosocial correlates of dietary intake of African-American girls. Obes Res 12, (Suppl), 20S-31S.
36. Cullen KW, Baranowski T, Owens E, Marsh T, Rittenberry L \& de Moor C (2003) Availability, accessibility, and preferences for fruit, $100 \%$ fruit juice, and vegetables influence children's dietary behavior. Health Educ Behav 30, 615-626.

37. Cullen KW, Baranowski T, Rittenberry L, Cosart C, Hebert D \& de Moor C (2001) Child-reported family and peer influences on fruit, juice and vegetable consumption: reliability and validity of measures. Health Educ Res 16, 187-200.

38. Cullen KW, Baranowski T, Rittenberry L, Cosart C, Owens E, Hebert D \& de Moor C (2000) Socioenvironmental influences on children's fruit, juice and vegetable consumption as reported by parents: reliability and validity of measures. Public Health Nutr 3, 345-356.

39. da Veiga GV \& Sichieri R (2006) Correlation in food intake between parents and adolescents depends on socioeconomic level. Nutr Res 26, 517-523.

40. De Bourdeaudhuij I \& Van Oost P (2000) Personal and family determinants of dietary behaviour in adolescents and their parents. Psychol Health 15, 751.

41. De Bourdeaudhuij I, Yngve A, Te Velde SJ, Klepp KI, Rasmussen M, Thorsdottir I, Wolf A \& Brug J (2006) Personal, social and environmental correlates of vegetable intake in normal weight and overweight 9 to 13-year old boys. Int J Behav Nutr Phys Act 3, 37.

42. Djuric Z, Cadwell WF, Heilbrun LK, Venkatramanamoorthy R, Dereski MO, Lan R \& Casey RJ (2006) Relationships of psychosocial factors to dietary intakes of preadolescent girls from diverse backgrounds. Matern Child Nutr 2, 79-90.

43. Edmonds J, Baranowski T, Baranowski J, Cullen KW \& Myres D (2001) Ecological and socioeconomic correlates of fruit, juice, and vegetable consumption among AfricanAmerican boys. Prev Med 32, 476-481.

44. Gibson EL, Wardle J \& Watts CJ (1998) Fruit and vegetable consumption, nutritional knowledge and beliefs in mothers and children. Appetite 31, 205-228.

45. Giskes K, Turrell G, Patterson C \& Newman B (2002) Socioeconomic differences in fruit and vegetable consumption among Australian adolescents and adults. Public Health Nutr 5, 663-669.

46. Haapalahti M, Mykkanen H, Tikkanen S \& Kokkonen J (2003) Meal patterns and food use in 10- to 11-year-old Finnish children. Public Health Nutr 6, 365-370.

47. Hanson NI, Neumark-Sztainer D, Eisenberg ME, Story M \& Wall M (2005) Associations between parental report of the home food environment and adolescent intakes of fruits, vegetables and dairy foods. Public Health Nutr 8, 77-85.

48. Hearn M, Baranowski T, Baranowski J, Doyle C, Smith M \& Lin LS (1998) Environmental influences on dietary behavior among children: availability and accessibility of fruits and vegetables enable consumption. J Health Educ 29, 26-32.

49. Hoglund D, Samuelson G \& Mark A (1998) Food habits in Swedish adolescents in relation to socioeconomic conditions. Eur J Clin Nutr 52, 784-789.

50. Johansen A, Rasmussen S \& Madsen M (2006) Health behaviour among adolescents in Denmark: influence of school class and individual risk factors. Scand J Public Health 34, 32-40.

51. Kratt P, Reynolds K \& Shewchuk R (2000) The role of availability as a moderator of family fruit and vegetable consumption. Health Educ Behav 27, 471-482.

52. Kremers SP, Brug J, de Vries H \& Engels RC (2003) Parenting style and adolescent fruit consumption. Appetite 41, 43-50

53. Kristjansdottir AG, Thorsdottir I, De Bourdeaudhuij I, Due P, Wind M \& Klepp KI (2006) Determinants of fruit and vegetable intake among 11-year-old schoolchildren in a 
country of traditionally low fruit and vegetable consumption. Int J Behav Nutr Phys Act 3, 41.

54. Larson NI, Story M, Eisenberg ME \& Neumark-Sztainer D (2006) Food preparation and purchasing roles among adolescents: associations with sociodemographic characteristics and diet quality. J Am Diet Assoc 106, 211-218.

55. Lien N, Jacobs DR Jr \& Klepp KI (2002) Exploring predictors of eating behaviour among adolescents by gender and socio-economic status. Public Health Nutr $\mathbf{5}$, 671-681.

56. Longbottom PJ, Wrieden WL \& Pine CM (2002) Is there a relationship between the food intakes of Scottish 5(1/2)-8(1/2)-year-olds and those of their mothers? J Hum Nutr Diet 15, 271-279.

57. Lowry R, Kann L, Collins JL \& Kolbe LJ (1996) The effect of socioeconomic status on chronic disease risk behaviors among US adolescents. JAMA 276, 792-797.

58. Lytle LA, Varnell S, Murray DM, Story M, Perry C, Birnbaum AS \& Kubik MY (2003) Predicting adolescents' intake of fruits and vegetables. J Nutr Educ Behav 35, 170-175.

59. Margarey A \& Boulton J (1997) The Adelaide Nutrition Study 5. Differences in energy, nutrient and food intake at ages 11, 13 and 15 years according to fathers occupation and parents educational level. Aust J Nutr Diet 54, 15-23.

60. Martens MK, van Assema P \& Brug J (2005) Why do adolescents eat what they eat? Personal and social environmental predictors of fruit, snack and breakfast consumption among 12-14-year-old Dutch students. Public Health Nutr 8, 1258-1265.

61. Matheson DM, Robinson TN, Varady A \& Killen JD (2006) Do Mexican-American mothers' food-related parenting practices influence their children's weight and dietary intake? J Am Diet Assoc 106, 1861-1865.

62. Melnik TA, Rhoades SJ, Wales KR, Cowell C \& Wolfe WS (1998) Food consumption patterns of elementary schoolchildren in New York City. J Am Diet Assoc 98, 159-164.

63. Neumark-Sztainer D, Hannan PJ, Story M, Croll J \& Perry C (2003) Family meal patterns: associations with sociodemographic characteristics and improved dietary intake among adolescents. I Am Diet Assoc 103, 317-322.

64. Neumark-Sztainer D, Story M, Resnick MD \& Blum RW (1996) Correlates of inadequate fruit and vegetable consumption among adolescents. Prev Med 25, 497-505.

65. Neumark-Sztainer D, Wall M, Perry C \& Story M (2003) Correlates of fruit and vegetable intake among adolescents. Findings from Project EAT. Prev Med 37, 198-208.

66. Omidvar N, Ghazi-Tabatbaie M, Eghtesadi S, Harrison G \& Miinaie S (2003) Psychosocial correlates of low fruit and vegetable intake among adolescent boys and girls in Tehran, Iran. Ecol Food Nutr 42, 385-397.

67. Reinaerts E, de Nooijer J, Candel M \& de Vries N (2006) Explaining school children's fruit and vegetable consumption: the contributions of availability, accessibility, exposure, parental consumption and habit in addition to psychosocial factors. Appetite 48, 248-258.

68. Roos EB, Hirvonen T, Mikkila V, Karvonen S \& Rimpela M (2001) Household educational level as a determinant of consumption of raw vegetables among male and female adolescents. Prev Med 33, 282-291.

69. Shi Z, Lien N, Kumar BN \& Holmboe-Ottesen G (2005) Socio-demographic differences in food habits and preferences of school adolescents in Jiangsu Province, China. Eur J Clin Nutr 59, 1439-1448.

70. Story M, Neumark-Sztainer D, Resnick MD \& Blum RW (1998) Psychosocial factors and health behaviors associated with inadequate fruit and vegetable intake among American-Indian and Alaska-Native adolescents. J Nutr Educ 30, 100-106.

71. Sweeting H, Anderson A \& West P (1994) Socio-demographic correlates of dietary habits in mid to late adolescence. Eur J Clin Nutr 48, 736-748.

72. Vereecken CA, Inchley J, Subramanian SV, Hublet A \& Maes $\mathrm{L}$ (2005) The relative influence of individual and contextual socio-economic status on consumption of fruit and soft drinks among adolescents in Europe. Eur J Public Health 15, 224-232.

73. Vereecken CA, Maes L \& De Bacquer D (2004) The influence of parental occupation and the pupils' educational level on lifestyle behaviors among adolescents in Belgium. J Adolesc Health 34, 330-338.

74. Videon TM \& Manning CK (2003) Influences on adolescent eating patterns: the importance of family meals. $J$ Adolesc Health 32, 365-373.

75. Wardle J, Jarvis MJ, Steggles N, Sutton S, Williamson S, Farrimond H, Cartwright M \& Simon AE (2003) Socioeconomic disparities in cancer-risk behaviors in adolescence: baseline results from the Health and Behaviour in Teenagers Study (HABITS). Prev Med 36, 721-730.

76. Wind $M$, de Bourdeaudhuij I, Te Velde SJ, Sandvik C, Due P, Klepp KI \& Brug J (2006) Correlates of fruit and vegetable consumption among 11-year-old BelgianFlemish and Dutch schoolchildren. J Nutr Educ Behav 38, 211-221.

77. Wolfe WS \& Campbell CC (1993) Food pattern, diet quality, and related characteristics of schoolchildren in New York State. J Am Diet Assoc 93, 1280-1284.

78. Woodward DR (1986) What influences adolescent food intakes? Hum Nutr Appl Nutr 40, 185-194.

79. Woodward DR (1985) Teenagers and their food: the effects of physical, behvaioural and socio-economic characteristics on intakes of five food categories in Tasmania. J Food Nutr 42, 7-12.

80. Woodward DR, Boon JA, Cumming FJ, Ball PJ, Williams HM \& Hornsby H (1996) Adolescents' reported usage of selected foods in relation to their perceptions and social norms for those foods. Appetite 27, 109-117.

81. Xie B, Gilliland FD, Li YF \& Rockett HR (2003) Effects of ethnicity, family income, and education on dietary intake among adolescents. Prev Med 36, 30-40.

82. Young EM \& Fors SW (2001) Factors related to the eating habits of students in grades 9-12. J Sch Health 71, 483-488.

83. Young EM, Fors SW \& Hayes DM (2004) Associations between perceived parent behaviors and middle school student fruit and vegetable consumption. J Nutr Educ Behav 36, 2-8.

84. Zabinski MF, Daly T, Norman GJ, Rupp JW, Calfas KJ, Sallis JF \& Patrick K (2006) Psychosocial correlates of fruit, vegetable, and dietary fat intake among adolescent boys and girls. J Am Diet Assoc 106, 814-821.

85. Haerens L, Craeynest M, Deforche B, Maes L, Cardon G \& De Bourdeaudhuij I (2007) The contribution of psychosocial and home environmental factors in explaining eating behaviours in adolescents. Eur J Clin Nutr 62, 51-59. 